
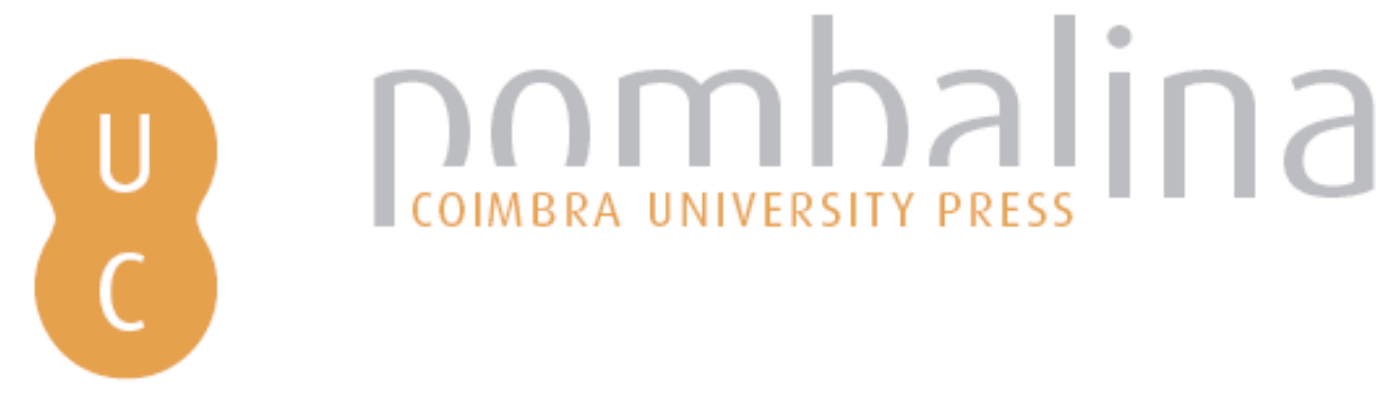

\title{
Estimating age at death in sdults from degenerative changes in the sternal end of the clavicle: preliminary results using a bayesian approach
}

\author{
Autor(es): $\quad$ Faria, F.; Andrade, M.; Cardoso, H. F. V. \\ Publicado por: Imprensa da Universidade de Coimbra; International Academy of Legal \\ URL \\ persistente: URI:http://hdl.handle.net/10316.2/31716 \\ DOI: DOI:http://dx.doi.org/10.14195/978-989-26-0173-1_6 \\ Accessed : $\quad$ 26-Apr-2023 13:10:40
}

A navegação consulta e descarregamento dos títulos inseridos nas Bibliotecas Digitais UC Digitalis, UC Pombalina e UC Impactum, pressupõem a aceitação plena e sem reservas dos Termos e Condições de Uso destas Bibliotecas Digitais, disponíveis em https://digitalis.uc.pt/pt-pt/termos.

Conforme exposto nos referidos Termos e Condições de Uso, o descarregamento de títulos de acesso restrito requer uma licença válida de autorização devendo o utilizador aceder ao(s) documento(s) a partir de um endereço de IP da instituição detentora da supramencionada licença.

Ao utilizador é apenas permitido o descarregamento para uso pessoal, pelo que o emprego do(s) título(s) descarregado(s) para outro fim, designadamente comercial, carece de autorização do respetivo autor ou editor da obra.

Na medida em que todas as obras da UC Digitalis se encontram protegidas pelo Código do Direito de Autor e Direitos Conexos e demais legislação aplicável, toda a cópia, parcial ou total, deste documento, nos casos em que é legalmente admitida, deverá conter ou fazer-se acompanhar por este aviso.

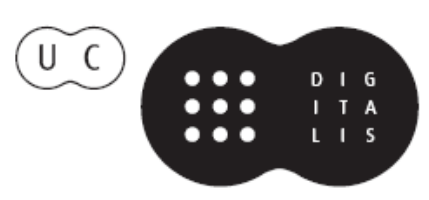




\section{Duarte Nuno Vieira Anthony Busuttil \\ Denis Cusack • Philip Beth}
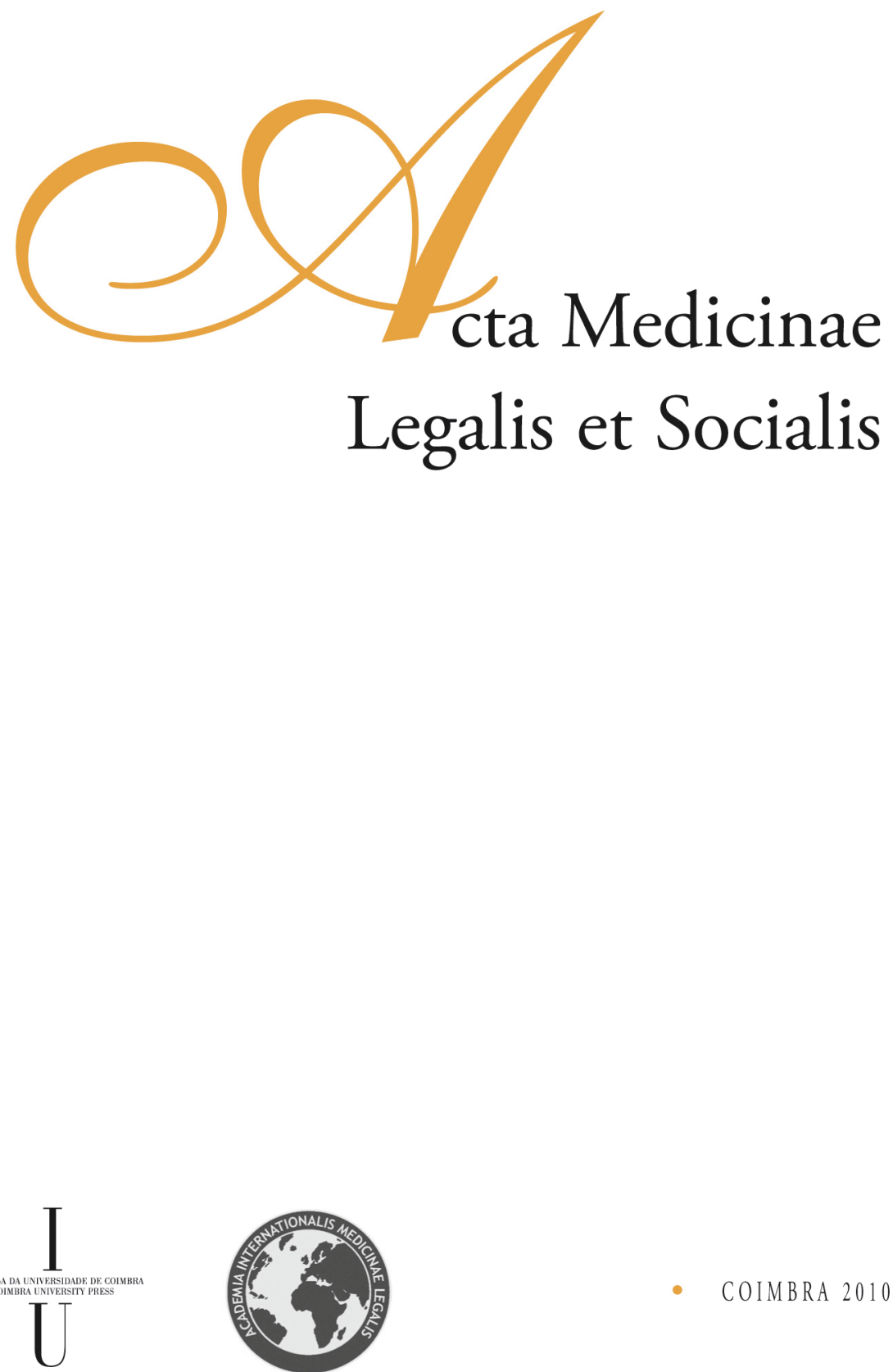
F. Faria ${ }^{1,2}$, M. Andrade ${ }^{3}$, H. F. V. Cardoso ${ }^{4,5}$

${ }^{1}$ Anthropology and Health Research Center (CIAS), University of Coimbra, Portugal

${ }^{2}$ Faculty of Sciences of the University of Lisbon (FCUL), Portugal

${ }_{3}^{3}$ Applied Sciences in Work and Enterprise University (ISCTE), Lisbon University Institute, Portugal

${ }^{4}$ National Museum of Natural History, Environmental Biology Centre, Lisbon, Portugal

${ }^{5}$ Faculty of Medicine of the University of Oporto, Portugal

\title{
ESTIMATING AGE AT DEATH IN ADULTS FROM DEGENERATIVE CHANGES IN THE STERNAL END OF THE CLAVICLE - PRELIMINARY RESULTS USING A BAYESIAN APPROACH
}

\begin{abstract}
Age estimation of adult skeletal remains is still a very uncertain procedure. This study represents an attempt to decrease the estimation error associated with adult age estimation in a forensic context, by using alternative bone indicators and statistical approaches. A sample of 91 known-age adult skeletons ( 47 females and 44 males) from the Spitalfields skeletal collection housed at the Natural History Museum in London was used. Five age-related variables were assessed on the sternal end of the clavicle: microporosity $(<1 \mathrm{~mm})$; macroporosity $(>1 \mathrm{~mm})$, sclerosis; new bone formation and marginal lipping. Ages where categorized in ten-year intervals and multinomial regression was used to estimate the probability of an individual being in a certain age interval conditional on the observed data (skeletal indicators). Results presented here are considered preliminary and illustrative of alternative skeletal indicators for age estimation in adults using a Bayesian approach.
\end{abstract}

\section{Introduction}

Estimating age at death of adult skeletal remains has been one of the greatest challenges in anthropological research. Most existing methods fail to provide an accurate estimate, particularly in individuals over 40-50 years of age (eg. Brooks and Suchey, 1990). In addition, the various methods have been developed over a limited number of anatomical locations, such as the pubic symphysis, the auricular surface or the sternal end of the ribs. Alternative sites have potential to provide additional age-related changes. The only two studies that uses the clavicle to estimate adult age at death were conducted by De Palma (1957), which described changes in the articular discs of the sternal end; and Miles (1999) who established a five grade categorization for age related changes for the acromial end. In this study we test the accuracy of age estimation using the degenerative process occurring at the sternal end of the clavicle. The results presented here are only preliminary, and are part of a larger study that comprises several collections of identified skeletons. The remaining data is still being collected, and it is hoped that the larger sample allows us to achieve more satisfying results in order to obtain a new and more reliable methodology to estimate age at death. 


\section{Goals}

This study comprises two main goals. The first is to assess the association between age and degenerative changes in the sternal end of the clavicle. The second goal is to test the adequacy of a Bayesian approach (Multinomial regression) to model our data for predictive purposes.

\section{Materials and Methods}

Ninety one skeletons ( 47 female and 44 male) from the Spitalfields Collection of Skeletons, housed at the Natural History Museum in London, between the ages of 30 and 91(Figure 1). All the clavicles were observed macroscopically using a 5x magnifying glass, and all were photographed. Five age-related variables were assessed: microporosity $(<1 \mathrm{~mm})$; macroporosity $(>1 \mathrm{~mm})$, sclerosis; new bone formation $(\mathrm{NBF})$ and marginal lipping. The first four variables were recorded according to the percentage of surface affected $(0-0 \% ; 1-1-24 \% ; 2-25-49 \% ; 3-50-74 \% ; 4-75-100 \%)$ and marginal lipping was recorded according to the size of the osteophytes. Spearman correlation and Multinomial Regression was undertaken using the statistical package SPSS 17.

\section{Data Processing}

Age was transformed in 10-year classes (starting at 30 years old). Observations in percentage were coded as explained above, however, we were not able to use this initial recording because there were too many zero cells, i.e. dependent variable levels by subpopulation with zero frequencies, so we were forced to find a new coding that reduced the number of stages in each variable and combined them with others in order to be better suited with the reality of our data. For example for microporosity the final encoding was: 0 - no changes; 1 only microporosity (regardless of the percentage); $2-0-24 \%$ of micro along with any other change; 3 - over $25 \%$ of micro along with other change. A Score variable (Similar to the one used by Buckberry and Chamberlain, 2002) was also calculated as the sum of the codes for each variable. This variable was also encoded: 1 - when sum was 0,1 or $2 ; 2$ - when 3,4 or $5 ; 3$ - when 6,7 or 8 . This new variable was used to test if age progression could be better explained by a combination of variables. Figures 2 and 3 show that there is a tendency for higher scores to be associated with elderly individuals.

\section{Results and Discussion}

Table 1 shows that the variables are differently correlated with age. Although in females almost all variables (lipping is the exception) have a significant correlation with age, the three significant correlations in males (sclerosis, NBF and Score) have a stronger correlation coefficient, although in none of the cases the correlation is higher than 0,540 . These results rule out lipping as an important variable. 
Using Multinomial Regression three steps were taken:

The first step was to test whether the male and female models were statistically significant, our hypothesis were:

H0: The model is not statistically significant vs. H1: The model is statistically significant

The model obtained for males includes only one of the measured variables (sclerosis) and the score. Table 2 shows the statistical results that allowed us to accept the model. $\mathrm{G}^{2}(25)=31,821 ; \mathrm{p}=0,007$, so we reject $\mathrm{H} 0$ and, therefore conclude that at least one independent variable has significant influence on age.

The model obtained for females includes three measured variables (microporosity, sclerosis and NBF) (Table 3). A parallel analysis to this model tells us that the it is also significant $\left(\mathrm{G}^{2}(35)=61,384 ; \mathrm{p}=0,004\right)$ (Table 2$)$.

Looking at the male and female models we can see that the male model has lower $\mathrm{AIC/BIC}$ values which mean that the final model obtained is better adjusted than the null model in the male group.

A second step was to test whether the model fitted the data, in this case the htpothesis were:

\section{H0: The model fits the data vs. H1: The model does not fit the data}

$\mathrm{H} 0$ is not rejected neither in the male nor female model, meaning that it fits the data in both sexes, in both statistics calculated (Deviance and Pearson). (More detailed results are not shown).

A third and final step was to calculate the multinomial regression model for each sex and age class. We obtained 12 regression formulae. The formulae for females and age class 2 (40-50 years) is shown in figure 4 .

\section{Conclusion}

Although the data collection is not complete, results indicate that there is some potential in this new method. Both models were found statistically significant, and the correlations were also significant (especially in females). At this stage the method seems to work better in females, which in our opinion, is to be expected, since we hypothesize that women in the sample experienced more homogenous activity levels (most were housewifes) than men, thus possibly reducing the effect of environmental factors related to activity. We expect that with the future three-fold increase in data, some of these difficulties will be overcome and the models will be more accurate.

\section{Acknowledgements}

This project was funded by the SYNTHESIS program (reference GB-TAF-4898). We want to thank the NHM of London for granting us access to the Spitalfields collection. We also wish to thank Robert Kruszinski, Louise Humphrey and Silvia Bello for all their help during the collection of data at the NHM. 


\section{References}

BROOKS S and SUCHEY JM, Skeletal age determination based on the os pubis: A comparison of the Acsádi-Nemeskéri and Suchey-Brooks methods. Hum Evol 5(3):227-238, 1990.

BUCKBERRY JL and CHAMBERLAIN AT, Age Estimation from the Auricular Surface of the Ilium: A Revised Method. Am J of Phys Anthropol 119:231-239, 2002.

DEPALMA AF, Degenerative Changes in the Sternoclavicular and Acromioclavicular Joints in Various Decades. Illinois: C.C. Thomas, 1957.

MILES AEW, A Five-grade Categorization of Age-related Change in the Acromio-clavicular Joint Derived from the Skeletal Remains of Early $19^{\text {th }}$ Century Londoners of Known Sex and Age, Intr J Osteoarchaeol, 9:83-101, 1999

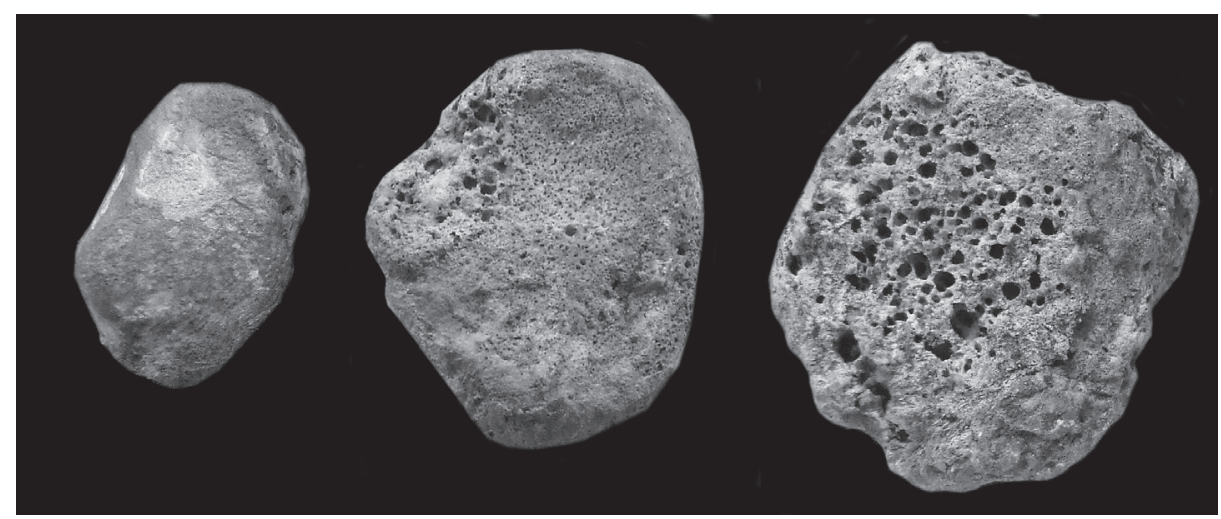

Figure 1 - Examples of observed clavicles. From left to right: specimen 2500 (female, age 37, almost no changes); specimen 2419 (male, age 63, some sclerosis clear in the upper left quadrant); specimen 2538 (male, age 81 sclerosis covers most of articular surface).

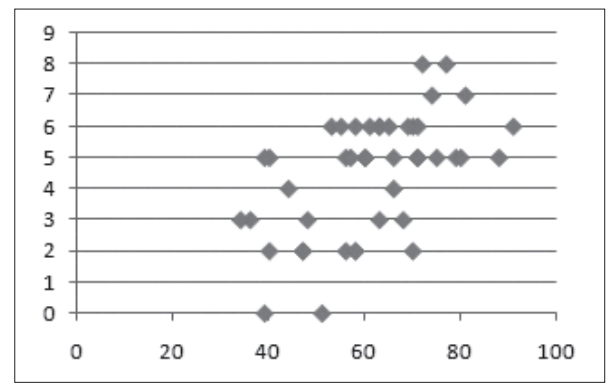

Figure 2 - Score vs. Age for males

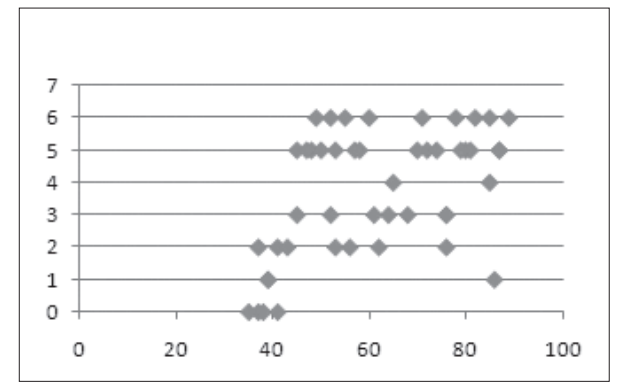

Figure 3 - Score vs. Age for females

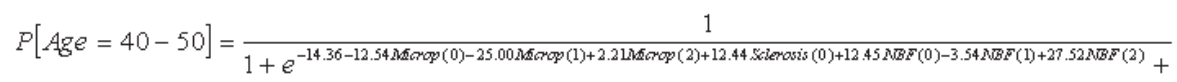

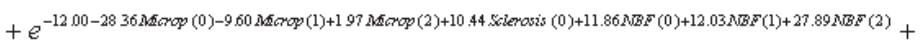

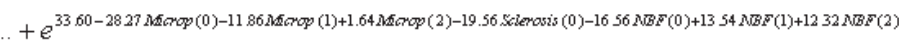

Figure 4 - Model equation obtained for females in age class 2 . 


\begin{tabular}{|c|c|c|c|c|c|c|c|}
\hline & & Microporisity & Macroporosity & Sclerosis & $\begin{array}{l}\text { New Bone } \\
\text { Formation }\end{array}$ & Lipping & Score \\
\hline \multirow[t]{3}{*}{ Male } & Correlation coefficient & 0,241 & 0,241 & $0,414^{* \star}$ & $0,540^{\star \star}$ & 0,065 & $0,415^{\star \star}$ \\
\hline & Sig. (2 tailed) & 0,200 & 0,115 & 0,005 & 0,000 & 0,675 & 0,005 \\
\hline & $\mathrm{N}$ & 44 & 44 & 44 & 44 & 44 & 44 \\
\hline \multirow[t]{5}{*}{ Female } & Correlation coefficient & $0,377^{\star \star}$ & $0,385^{\star \star}$ & $0,300^{*}$ & $0,296^{*}$ & 0,273 & $0,466^{* *}$ \\
\hline & Sig. (2 tailed) & 0,009 & 0,007 & 0,041 & 0,043 & 0,063 & 0,001 \\
\hline & $\mathrm{N}$ & 47 & 47 & 47 & 47 & 47 & 47 \\
\hline & \multicolumn{4}{|c|}{${ }^{\star \star}$ - Correlation is significant at the 0.01 level (2-tailed) } & & & \\
\hline & \multicolumn{4}{|c|}{${ }^{*}$ - Correlation is significant at the 0.05 level (2-tailed) } & & & \\
\hline
\end{tabular}

Table 1 - Spearman correlation between each variable and age.

\begin{tabular}{|c|l|r|r|r|r|r|r|}
\hline \multirow{2}{*}{ Model } & \multicolumn{4}{|c|}{ Model Fitting Criteria } & \multicolumn{3}{c|}{ Likelihood Ratio Tests } \\
\cline { 3 - 9 } & \multicolumn{1}{|c|}{ AIC } & BIC & -2 Log Likelihood & Chi-Square & df & Sig. \\
\hline \multirow{3}{*}{ Males } & $\begin{array}{l}\text { Intercept } \\
\text { Only }\end{array}$ & 70,652 & 79,573 & 60,652 & & & \\
\cline { 2 - 9 } & Final & 68,831 & 104,515 & 28,831 & 31,821 & 15 & 0,007 \\
\hline \multirow{3}{*}{ Females } & $\begin{array}{l}\text { Intercept } \\
\text { Only }\end{array}$ & 106,606 & 115,857 & 96,606 & & & \\
\cline { 2 - 9 } & Final & 115,222 & 189,228 & 35,222 & 61,384 & 35 & 0,004 \\
\hline
\end{tabular}

Table 2 - Model statistics

\begin{tabular}{|c|c|c|c|c|c|c|c|}
\hline \multirow{2}{*}{\multicolumn{2}{|c|}{ Effect }} & \multicolumn{3}{|c|}{ Model Fitting Criteria } & \multicolumn{3}{|c|}{ Likelihood Ratio Tests } \\
\hline & & $\begin{array}{c}\text { AlC of } \\
\text { Reduced }\end{array}$ & $\begin{array}{c}\text { BIC of } \\
\text { Reduced }\end{array}$ & -2 Log Likelihood & Chi- & & \\
\hline \multirow{2}{*}{ Males } & Sclerosis & 70,439 & 97,202 & 40,439 & 11,608 & 5 & 0,041 \\
\hline & Score & 67,455 & 85,297 & 47,455 & 18,624 & 10 & 0,045 \\
\hline \multirow{3}{*}{ Females } & Sclerosis & $\overline{116,011}$ & $\overline{180,766}$ & 46,011 & 10,789 & 5 & 0,056 \\
\hline & NBF & 108,375 & 154,629 & 58,375 & 23,153 & 15 & 0,081 \\
\hline & Microporosity & 111,376 & 157,630 & 61,376 & 26,154 & 15 & 0,036 \\
\hline
\end{tabular}

Table 3 - Variables in each model (male and female). 